\title{
Facial analysis in Down's Syndrome patients
}

\author{
Análise facial em pacientes com Sindrome de Down
}

Lorena Nielsen DAMASCENO'

Roberta Tarkany BASTING ${ }^{1}$

\section{ABSTRACT}

\section{Objective}

The aim of this study was to analyze the facial features of patients with Down syndrome, such as projection of the nose, projection and length of upper and lower lips, projection of soft pogonion and to compare them with the standardized analysis by Ayala and Gutierrez'.

\section{Methods}

The sample consisted of 20 patients with Down's Syndrome, between 8 and 13 years-old of both genders. The analysis was performed by one orthodontist, using lateral cephalograms and photography in natural head position. For statistical analysis, the mean values of linear measurements within a range of $95 \%$ were used.

\section{Results}

The mean ( \pm standard deviation) showed a nasal projection of $10.1 \mathrm{~mm}(2.4)$, the upper and lower lip in front of the vertical reference line, subnasal and soft pogonion with a retrusion of $4.95 \mathrm{~mm}$ (4.6). The length of the upper lip showed a value of $20.2 \mathrm{~mm}(2.4)$ and the length of the lower lip of $42.5 \mathrm{~mm}(2.9)$.

\section{Conclusion}

The facial analysis of patients with Down's Syndrome, compared with Ayala and Gutierrez', showed smaller nasal projection, greater projection of the upper and lower lip, but lengths, and retrusion of the soft pogonion, similar to those of normal individuals

Indexing terms: Cephalometry. Down Syndrome. Facial bones.

\section{RESUMO}

\section{Objetivo}

Realizar uma análise das características faciais dos pacientes com Síndrome de Down quanto à projeção do nariz, projeção e comprimento dos lábios superior e inferior e projeção do pogônio mole e compará-las com a análise padronizada por Ayala \& Gutierrez"

\section{Métodos}

A amostra foi composta por 20 pacientes portadores da Síndrome de Down com idade entre 8 a 13 anos de ambos os gêneros. A análise foi efetuada por um único ortodontista, utilizando telerradiografias em norma lateral e fotografia em posição natural da cabeça. Para a análise estatística foram utilizados os valores de média das medidas lineares dentro de um intervalo de confiança de $95 \%$.

\section{Resultados}

As médias (+ desvio padrão) revelaram uma projeção nasal de 10,1 mm $(2,4)$, o lábio superior e inferior à frente da linha de referência vertical, subnasal e pogônio mole com uma retrusão de $4,95 \mathrm{~mm}(4,6)$. O comprimento do lábio superior apresentou valor de $20,2 \mathrm{~mm}(2,4)$ e o comprimento do lábio inferior de $42,5 \mathrm{~mm}(2,9)$.

\section{Conclusão}

Conclui-se que pacientes com Síndrome de Down apresentaram em sua análise facial ao se comparar com Ayala \& Gutierrez menor projeção nasal, maior projeção do lábio superior e inferior, mas comprimentos semelhantes ao de indivíduos normais, e maior retrusão do pogônio mole.

Termos de indexação: Circunferência craniana. Síndrome de Down. Ossos faciais.

\footnotetext{
${ }^{1}$ Faculdade São Leopoldo Mandic, Curso de Odontologia, Departamento de Dentística. Rua José Rocha Junqueira, 13, Swift, 13045-755, Campinas, SP, Brasil. Correspondência para / Correspondence to: RT BASTING. E-mail: <rbasting@yahoo.com>
} 


\section{INTRODUCTION}

Among the congenital defects that have most aroused the interest of clinicians and researchers, are those of the Down Syndrome, whose most clinical manifestations were described for the first time by John Langdon Down, in $1866^{2}$. Persons with Down Syndrome present 47 chromosomes in each cell, instead of 46 , as others do. This extra chromosome is located in pair $21^{3}$. According to Mustachi \& Peres ${ }^{4}$, the Down Syndrome may be caused by three types of chromosomal changes: Free trisomy, mosaicism and translocation. However, there is no difference in clinical aspect between the different types, and they are only differentiated in exams of the chromosomes of blood cells.

Down Syndrome is essentially a delay in development, of both motor functions of the body and mental functions, popularly known as Mongolism. The name Mongolism was given due to the folds in the corners of the eyes which remind one of the appearance of persons of the Mongolian race ${ }^{5}$. Many articles have been published relating the main manifestations present in this syndrome, which in Brazil, presents a prevalence of 1:600 births, according to the World Health Organization. Among these manifestations, the outstanding features are the presence of mental retardation, muscle hypotonia, upslanted palpebral fissure, flattened occiput, broad hands and short fingers, clinodactyly of the fifth finger, epicanthal folds in the eyes, single palmar crease, low set ears, brachycephalia, low stature, congenital cardiopathies, sterility and oral and facial manifestations ${ }^{6}$ (such as palatal atresia, fissured tongue, macroglossia, periodontal disease, conoid teeth, ageneses and supranumerary teeth).

Mustachi \& Rozone ${ }^{7}$ related that there are constant changes in the shape of the arches, in the relation between the arches in the vertical, transverse and anteroposterior directions, and the help of an orthodontist is frequently required for correction of occlusal balance. There must also be an associated facial exam, this being the key to diagnosis and making therapeutic decisions ${ }^{1}$. Furthermore, Vaden ${ }^{8}$ mentioned that the face must be the orthodontist's main concern, and that when considering facial disharmony, one would need to have an intuitive concept of how one would achieve facial balance. The existence of three factors that influence facial balance must be considered, these being the positions of the teeth, skeletal pattern and soft tissue dimensions. In the case of the disharmony being a consequence of the abnormal skeletal relation, the orthodontist would need to evaluate the possibility of compensating this abnormal relation with a change in the position of the teeth, in conjunction with considering the soft tissue imbalances.

Therefore, the pathognomonic facial characteristics of Down Syndrome because of the altered facial development, particularly of the middle third of the face that is diminished, which must be considered in association with the abnormal development of the skull9-10, arouse the interest of researchers in the area of Dentistry, especially in Orthodontics, when seeking to establish parameters for the diagnosis, planning and even treatment, suited to the limitations of the syndrome.

\section{METHODS}

From the database of the dental clinic "Clínica Odontológica Villa Odonto Ltda.," with its headquarters in Vitória in the state of Espírito Santo, Brazil, a facial analysis was performed, using lateral photographs of the face with the head in a natural position, and lateral teleradiographs. The sample was formed by 20 patients with Down Syndrome, of the male (10 patients) and female (10 patients) gender, selected by convenience.

The cephalogram was delineated manually by a radiologist with over 15 years of experience, from the lateral teleradiographs of the patients. The anatomic structures, cephalometric points and cephalometric variables were delimitated after the cephalogram was transferred to the natural position of the head based on the photograph.

The criteria for inclusion in the sample were patients in the age-range between 8 and 13 years; who had orthodontic documentation; who were not being, or had never been submitted to orthodontic or orthopedic treatment, and who had been authorized by the parents or guardians to participate in the study, by signature of the Term of Free and Informed Consent.

The exclusion criterion was the patient whose orthodontic documentation and photograph had not been taken in the natural position of the head.

As the teleradiographs had not been taken with the individual's head in the natural position, in order to conduct the experiment, photographs obtained in the NPH were used to transfer this position to the cephalometric tracing, in accordance with the method used by Ayala \& Gutierrez': a) on the photograph, trace the Ricketts esthetic plane (tip of the nose - most anterior part of the soft chin); b) on the photograph, measure the angle 
formed by the intersection of the Ricketts esthetic plane and the true vertical line; c) on the cephalogram obtained from the teleradiograph, trace the Ricketts esthetic plane and transfer the angle obtained in step b. Obtaining the true vertical line; d) re-draw the cephalogram with the true vertical line parallel to the margins of the paper used.

After concluding transfer of the cephalograms, the following cephalometric points were demarcated: a) pronasal $(\mathrm{Pn})$ - most prominent point of the nose in the soft profile; b) subnasal (Sn) - point located at the intersection of the upper lip and base of the nose; c) upper lip (Ls) point located in the most anterior region of the red portion of the upper lip; d) botttom lip (Li) - point located in the most anterior region of the red portion of the bottom lip; e) soft pogonion (Pog') - most prominent (anterior) point of the outline of the soft chin.

The following lines of reference were traced: a) the true vertical line $(\mathrm{VV})$; b) true horizontal line $(\mathrm{HV})$ : line perpendicular to the true vertical line; c) vertical subnasal line $(\mathrm{SnV})$ : perpendicular to the true horizontal passing through the subnasal point.

The following horizontal cephalometric variables were evaluated (Figure 1): a) SnV - Pn: distance perpendicular to the vertical subnasal line to the pronasal point; b) SnV - Ls: distance perpendicular to the vertical subnasal line to the upper lip point; b) SnV - Ls: distance perpendicular to the vertical subnasal line and the bottom lip point; b) SnV - Ls: distance perpendicular to the vertical subnasal line and the soft pogonion point; b) SnV - Ls:

If the point of the soft profile were located anteriorly to the vertical subnasal line, a positive value could be attributed, and if the point of the soft tissue were posterior to the line of reference, a negative value would be attributed. If the soft tissue point were tangent to the vertical line, it would receive the value zero.

In order to evaluate the vertical cephalometric variables the following points were demarcated: a) subnasal $(S n)$ - point located at the intersection of the upper lip and the base of the nose; b) stomion (St) - point located at the intersection of the dry lip with the wet lip; c) soft chin (Me') - point located in the most inferior portion of the soft chin.

Lines of reference were traced perpendicular to $\mathrm{V}$, starting from the three points described.

The following vertical variables were evaluated (Figure 1): a) Sn - St: Upper lip length, distance between the lines that pass through the points Sn and St perpendicular to the true vertical; b) St - Me': Bottom lip length, distance between the lines that pass through the points St - Me':

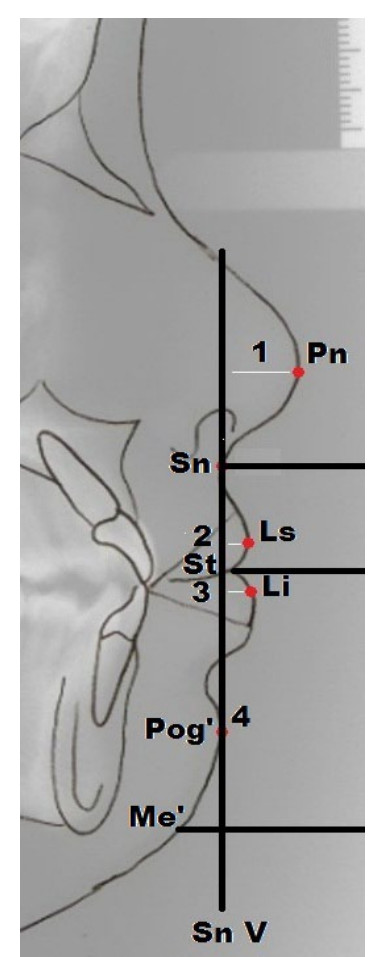

Figure 1. Cephalogram with demarcation of the variables analyzed.

The data obtained were organized and inserted into an Excel spreadsheet, where the prevalences were evaluated for the sample in accordance with the IC for each measurement evaluated. For the study variables SnV-Pn (projection of the nose), SnV-Ls (projection of the upper lip), SnV-Li (projection of the bottom lip); SnVPog (projection of the chin); LS (upper lip length) and LI (bottom lip length) descriptive statistics of the data were made (mean, standard deviation and interval of confidence at $95 \%)$.

This research project, under Protocol n. 2008/0175, was approved by the Research Ethics Committee of the São Leopoldo Mandic Dental School, in accordance with resolution 196/1.996 of the Ministry of Health.

\section{RESULTS}

Table 1 presents the distribution of the study sample according to gender and age.

Table 2 presents the mean and standard deviation values for each of the variables analyzed in the study for the patients with Down Syndrome, and the interval of confidence. 
Table 1. Distribution of sample according to gender and age.

\begin{tabular}{lccccc}
\hline & \multicolumn{2}{c}{ Female } & \multicolumn{3}{c}{ Male } \\
\hline Age (years) & $\mathrm{n}$ & $\%$ & $\mathrm{n}$ & $\%$ & $\mathrm{n}$ \\
\hline 8 & 3 & 33.3 & 6 & 66.7 & 9 \\
9 & 1 & 50.0 & 1 & 50.0 & 2 \\
10 & 0 & 0.0 & 2 & 100.0 & 2 \\
11 & 1 & 50.0 & 1 & 50.0 & 2 \\
12 & 2 & 100.0 & 0 & 0.0 & 2 \\
13 & 3 & 100.0 & 0 & 0.0 & 3 \\
\hline General total & 10 & 50.0 & 10 & 50.0 & 20 \\
\hline
\end{tabular}

Table 2. Study Variables, mean, standard deviation and interval of confidence at 95\%.

\begin{tabular}{lccc}
\hline & Mean & $\begin{array}{c}\text { Standard } \\
\text { deviation }\end{array}$ & IC95\% \\
\hline SnV-N (mm) & 10.1 & 2.4 & 9.1 a 10.09 \\
SnV-Ls (mm) & 5.7 & 3.0 & 4.50 a 6.75 \\
SnV-Li (mm) & 4.15 & 3.5 & 2.75 a 5.40 \\
SnV-Pog' (mm) & -4.95 & 4.6 & -6.95 a -3.25 \\
LS (mm) & 20.2 & 2.4 & 19.20 a 21.0 \\
LI (mm) & 42.5 & 2.9 & 41.25 a 43.65 \\
\hline
\end{tabular}

The means revealed a nasal projection of 10.1 $\mathrm{mm}$, the upper lip and bottom lip forward of the vertical subnasal and soft pogonion reference line with a retrusion of $4.95 \mathrm{~mm}$ in relation to the reference line. The length of the upper lip presented a value of $20.2 \mathrm{~mm}$ and that of the bottom lip, $42.5 \mathrm{~mm}$.

Table 3 shows the interval of confidence at 95\% and the interval of the norm standardized by Ayala \& Gutierrez'.

Table 3. Comparative analysis between the interval of the norm and interval of confidence at $95 \%$.

\begin{tabular}{lcc}
\hline & IC95\% & Norm \\
\hline SnV-N $(\mathrm{mm})$ & 9.1 a 10.09 & 16 a 20 \\
SnV-Ls $(\mathrm{mm})$ & 4.50 a 6.75 & 2 a 5 \\
SnV-Li $(\mathrm{mm})$ & 2.75 a 5.40 & 0 a 3 \\
SnV-Pog $(\mathrm{mm})$ & -6.95 a -3.25 & -4 a 0 \\
LS $(\mathrm{mm})$ & 19.20 a 21.0 & 20 a 22 \\
LI $(\mathrm{mm})$ & 41.25 a 43.65 & 40 a 44 \\
\hline
\end{tabular}

When comparing the values obtained with those recommended by Ayala \& Gutierrez ${ }^{1}$, diminished values for projection of the nose; increased values for projection of the upper lip and lower lip; retrusion of the soft pogonion and equal proportions for the length of both the upper and bottom lip were verified.

\section{DISCUSSION}

In this research, the option the study the facial profile by means of linear measurements was taken because it is one of the most understandable and easiest ways of visualizing it. Evaluation of the sagittal position of the nose, lips and soft chin, and length of both the upper lip and bottom lip was based on researches that observed the need for harmony among these structures ${ }^{1,11-12}$. In the studied population, the linear measurements SnV-Pn, SnVLS, SnV-Li, SnV-Pog',LS and LI were used with the intention of finding out the variation in facial characteristics of patients with Down Syndrome.

The nose of persons with Down Syndrome, in general, is small and associated with a low nasal point, with frequent absence of nasal bones ${ }^{13}$. When analyzing the projection of the nose, the mean value of 10.1 $(+2.4 \mathrm{~mm})$ found in the present study, confirmed the pathognomonic characteristic of the face of individuals with Down Syndrome related by these researchers. These values differ from those standardized by Ayala \& Gutierrez', which present an ideal value from 16 to $20 \mathrm{~mm}$.

The sample of adults used in the study of Ayala and Gutierrez ${ }^{7}$ presented an upper lip with a projection of 2 to $5 \mathrm{~mm}$, whereas in the present study it presented $5.7 \mathrm{~mm}$ $(+3 \mathrm{~mm})$. In the sample of Scavone Junior et al. ${ }^{14}$ studying a Nippo-Brazilian population, the values came closest to those of the present study, with the mean projection of the upper lip in the male gender being $4.74 \mathrm{~mm}(+2.5 \mathrm{~mm})$ and for the female gender, a mean of $4.09 \mathrm{~mm}(+1.95 \mathrm{~mm})$ was found. Approximate values between the present sample (Brazilian individuals with DS) and that of Scavone (sample of Brazilians), are in agreement with the assertion of Cohen $\&$ Winer ${ }^{15}$, who affirmed that although there is a single characteristic, racial and family similarities are commonly observed in patients with Down Syndrome.

When studying the projection of the bottom lip, a value of $4.15 \mathrm{~mm}(+3.5 \mathrm{~mm})$ was verified, while Ayala \& Gutierrez 1 attributed a projection of 0 to $3 \mathrm{~mm}$ to the bottom lip. This confirms the presence of pseudoprognathism which is the characteristic cited by Thompson ${ }^{16}$. The development of the mandible does not appear to have been so badly affected, which is considered in view of the 
deficiency in the middle third of the face and the relative normality of the mandible, in addition to the very small relationship with the skull.

With regard to the location of the soft pognion in relation to the subnasal vertical line in the present sample, the value of $-4.95 \mathrm{~mm}(+4.6 \mathrm{~mm})$ was found. Ayala \& Gutierrez ${ }^{1}$ believed that a pleasant profile must have a soft chin of -4 to $0 \mathrm{~mm}$ behind the vertical subnasal line. Fink et al. ${ }^{17}$ concluded that in persons with DS there is a reduction in the length of the base of the skull and a deficiency of the middle third of the face, and these deficiencies become more expressive with an increase in age, while the mandible grows in a manner similar to that in normal individuals.

As regards the height of the upper lip and bottom lip, the present sample presented the values of 20 and $42 \mathrm{~mm}$, respectively, and may be considered values within the norm when comparing the standardization proposed by Ayala \& Gutierrez ${ }^{1}$, which are 20 and $40 \mathrm{~mm}$, in a proportion of 1:2. This confirms the facial characteristic of patients with Down Syndrome described by Shapiro ${ }^{18}$, who affirmed that the hard palate is shown to be of normal height, but smaller and of an ogival shape, and may be considered only as being narrower and shorter.

However, it must be pointed out that the sample of this study consisted of patients with DS, with a mean age of 8 to 13 years, during which they still present growth of the nose, whereas in the study of Ayala \& Gutierrez ${ }^{1}$ the population consisted of young adults. According to Pozsony et al. ${ }^{19}$, skeletal maturation ceases at around 15 years of chronological age for DS individuals, whereas for normal individuals it occurs at around 18 years of age. In this study, the normative values attributed to a population of individuals with Down Syndrome could be recognized. Considering those with orthodontic objectives, their own facial characteristics must be considered, so that the orthodontic goals are not mistaken. Jesuíno and Valadares Neto $^{20}$ verified that patients with Down Syndrome differed from patients with Class III malocclusion and maxillary deficiency, with regard to the base of the skull being flat and the length of the maxilla being reduced. However, this maxillary deficiency is not so expressive in the face of syndromic patients, due to the generalized reduction in craniofacial dimensions. Therefore, when performing orthodontic treatment in a patient with Down Syndrome, in one's diagnosis, planning and prognosis one could initially consider that it concerns an individual with a Class III pattern, but who presents differentiations characterized by the syndrome. In the present study, in spite of the sample size being considered small, it was verified that the results presented contributed to a better evaluation of the syndromic patient, suggesting some reference values. However, exceptionally when one encounters individuals with Down Syndrome who present a Class I pattern, the patient's treatment should be conducted with the reference values existent in the literature for normal individuals. It should be emphasized that orthodontic professionals are committed to science, and therefore, they need to have the sensitivity to recognize the positive and negative characteristics of the face, and establish an individualized treatment plan, seeking integration of functional occlusion and facial harmony. Additional future studies are considered important and necessary, such as the study of Schlickmann et al. ${ }^{21}$ with computerized measurement, which is more precise for obtaining normative values for the group itself, allowing greater facility in diagnosis and orthodontic planning for the patient with Down Syndrome.

\section{CONCLUSION}

According to the results obtained, it was concluded that in their facial analysis, patients with Down Syndrome present smaller nasal projection, greater projection of the upper and bottom lip, but with similar lengths to those in normal individuals, and greater retrusion of the soft pogonion.

\section{Collaborators}

LN DAMASCENO was responsible for the experimental phase (data collection, sample selection, analysis of the results, review of the literature), and writing the article. RT BASTING was responsible for guidance, planning the experiment and writing the article.

\section{REFERENCES}

1. Ayala JP, Gutierrez GA. Tratamento da maloclusão de Classe II. In: Interlandi S. Ortodontia bases para a iniciação. $4^{a}$ ed. São Paulo: Artes Médicas; 1999. p. 329-76.
2. Rey SC, Fazzi R, Birman EG. Principais alterações craniofaciais em portadores da Síndrome de Down. Rev Fac Odontol FZL. 1991;3(1):59-64. 
3. Benatti AM, Campos MTGR, Zangilorami TR, Oliveira MCS, Casarin S. Diagnóstico pré-natal: anomalias cromossômicas: Síndrome de Down. In: Manual Projeto Down. São Paulo: Centro de informações e Pesquisa da Síndrome de Down; 1994.

4. Mustacchi Z, Peres S. Genética baseada em evidencias: síndromes e heranças. São Paulo: CID; 2000.

5. Desai SS, Fayetteville BDS. Down syndrome: a review of the literature. Oral Surg Oral Med Oral Pathol Oral Radiol. 1997:84(3):279-85. doi: 10.1016/S1079-2104(97)90343-7.

6. Coelho CRZ, Loevy HT. Aspectos odontológicos da Síndrome de Down. Ars Curandi Odontol. 1982;8(3):9-16.

7. Mustacchi Z, Rozone G. Síndrome de down: aspectos clínicos e odontológicos. São Paulo: CID; 1990.

8. Vaden JL. Orthodontic magic. Am J Orthod Dentofacial Orthop. 2000;117(5):584-5.

9. Sweard AF, Roche F, Sunderland $S$. The lateral cranial silhouette in mongolism. Aschs Oral Biol. 1961;85(4):653-8.

10. Suri S, Tompson BD, Cornfoot L. Cranial base, maxillary and mandibular morphology in Down syndrome. Angle Orthod. 2010;80(5):861-9. doi: 10.2319/111709-650.1.

11. Hsu BS. Comparisons of the five analytic reference lines of the horizontal lip position: their consistency and sensitivity. Am J Orthod Dentofac Orthop. 1993;104(4):355-60.

12. Epker BH, Stella JP, Fish LC. Dentofacial deformities. St. Louis: Mosby; 1995.

13. Frota - Pessoa O. Genética clínica. Rio de Janeiro: Francisco Alves; 1984.

14. Scavone Junior R, Zahn-Silva W, Vale-Corotti KM, Nahás ACR Soft tissue profile in White Brazilian adults with normal occlusions and well-balanced faces. Angle Orthod. 2006;78(1):58-63. doi: 10.2319/103006-447.1.
15. Cohen MM, Winer R. Dental and facial characteristics in Down's Syndrome (Mongolism). J Dent Res. 1965;44(1):197-208.

16. Thompson CDA. The palate in down's syndrome. The Dental Assistant. 1976;45(10):6-20. doi: 10.1056/ NEJM196706292762603.

17. Fink GB, Madaus WK, Walker JF. A quantitative study of the face in Down's syndrome. Am J Orthod. 1975;67(5):540-53.

18. Shapiro S. Periodontal disease and Blood Citrate level in patients with trisomy 21. J Dent Res.1969;48():1231-3. doi: 10.1177/00220345690480062401.

19. Pozsonyi J, Gibson D, Zarfas DE. Skeletal maturation in mongolism. (Down's syndrome). J Pediatric. 1964;64(1):75-8. doi 10.1016/S0022-3476(64)80319-X.

20. Jesuino FA, Valladares-Neto J. Craniofacial morphological differences between Down syndrome and maxillary deficiency children. Eur J Orthod. 2013 Feb;35(1):124-30. doi: 10.1093/ ejo/cjr105.

21. Schlickmann ICA, Moro A, Dos Anjos A. Análise do perfil facial masculino adulto jovem, esteticamente agradável, em fotografias padronizadas: comparação da medição manual com a computadorizada. Dental Press Ortodon Ortop Facial. 2008; 13(6):98-107. doi: 10.1590/S1415-54192008000600012.

Received on: 9/6/2010 Final version resubmitted on: 19/3/2012 Approved on: 2/4/2012 